\title{
BMJ Open Association of neck circumference with general and abdominal obesity in children and adolescents: the weight disorders survey of the CASPIAN-IV study
}

Roya Kelishadi, ${ }^{1}$ Shirin Djalalinia, ${ }^{2,3}$ Mohammad Esmaiel Motlagh, ${ }^{4}$ Ali Rahimi, ${ }^{5}$ Maryam Bahreynian, ${ }^{1}$ Tahereh Arefirad, ${ }^{6}$ Gelayol Ardalan, ${ }^{1}$ Saeid Safiri, ${ }^{7}$ Motahare Hasani, ${ }^{8}$ Hamid Asayesh, ${ }^{9}$ Morteza Mansourian, ${ }^{10}$ Mostafa Qorbani ${ }^{11,12}$

To cite: Kelishadi R, Djalalinia S, Motlagh ME, et al. Association of neck circumference with general and abdominal obesity in children and adolescents: the weight disorders survey of the CASPIAN-IV study. BMJ Open 2016;6:e011794. doi:10.1136/bmjopen-2016011794

- Prepublication history for this paper is available online. To view these files please visit the journal online (http://dx.doi.org/10.1136/ bmjopen-2016-011794).

Received 7 March 2016 Revised 6 June 2016 Accepted 22 June 2016

CrossMark

For numbered affiliations see end of article.

Correspondence to Dr Mostafa Qorbani; mqorbani1379@yahoo.com

\section{ABSTRACT}

Objectives: This study aimed to evaluate the association of neck circumference (NC) with obesity to determine the sex-specific and age-specific optimal cut-off points of this measure in association with obesity in a national sample of the Iranian paediatric population.

Methods: This survey on weight disorders was conducted among a national sample of Iranian children and adolescents, aged 6-18 years. Using the area under the curve (AUC) of the receiver operator characteristic curves, we evaluated the association of NC with general and abdominal obesity.

Results: This national survey was conducted among 23043 school students (50.8\% boys) with a mean age (SD) of 12.55 (3.31) years. A significant association was documented between NC and other anthropometric measures in both sexes and in the whole population. In all age groups and genders, NC performed relatively well in classifying participants to overweight (AUC: 0.67 to $0.75, p<0.001$ ), general obesity (AUC: 0.81 to $0.85, p<0.001$ ) and abdominal obesity (AUC: 0.73 to $0.78, p<0.001$ ).

Conclusions: NC can be considered as a simple timesaving clinical tool for obesity detection in large population-based studies in children and adolescents. It is significantly correlated with indices of adiposity and can reliably identify children with general and abdominal obesity in the Iranian paediatric population.

\section{INTRODUCTION}

Childhood overweight and obesity has become a worldwide public health priority. ${ }^{12}$ An accumulating body of evidence reveals the worldwide rapid growing prevalence of overweight/obesity in the paediatric age group. ${ }^{3} 4$ These alarming patterns are now emerging in developing countries like

\section{Strengths and limitations of this study}

Limited experience exists on the appropriateness of neck circumference as an anthropometric index. To the best of our knowledge, this is the first study in the Middle East and North Africa (MENA) region that evaluated the association of neck circumference with obesity.

- The large population-based sample size is a strength point of this study, and makes the results generalisable.

- The cross-sectional design of the study prevents us from deducing any causal relations between our findings.

- We were not able to measure fat mass as an indicator of obesity, so it was defined according to the body mass index.

Iran. ${ }^{5}{ }^{6}$ Situation analyses of problems in Iranian children and adolescents have shown that the prevalence of overweight and obesity is about $5 \%$ and $10 \%$, respectively. ${ }^{6}$

Body mass index (BMI) is the most widely used tool to assess the weight status in adults and children. ${ }^{7}$ Despite its advantages including ease of measurement and interpretation, BMI is associated with significant limitations as not representing the body fat distribution. ${ }^{8} 9$ Among other measures, wrist circumference is simple, easy to detect but not involved in the assessment of other parameters. ${ }^{10}$ Waist and hip circumferences have some difficulties in clinical measurements; clothing is one major disturbing factor complicating their measurement. ${ }^{11}$

Neck circumference (NC) has also been proposed as a potential proxy for obesity and cardiovascular disease in adults. ${ }^{6} 12 \quad 13$ NC measurement is a simple and time-saving 
screening measure that can be used to identify overweight and obese individuals. ${ }^{6}$ Some previous studies in adults documented that in various gender-age groups, NC, waist circumference (WC) and BMI are all highly correlated with each other. ${ }^{12}$ Some studies showed that $\mathrm{NC}$ performs well as an index of high BMI in young children and adolescents of both genders. ${ }^{12} 14$

Limited experience exists on using $\mathrm{NC}$ as a screening tool for obesity in children and adolescents, and studies are mostly limited to some specific groups. ${ }^{6} 12 \quad 14 \quad 15$ Considering the noticeable gaps in what is known about this topic, ${ }^{12} 16$ the objectives of this study are to evaluate the association of NC with obesity and to determine the sex-specific and age-specific optimal cut-off points of this measure that are associated with obesity in a national sample of the Iranian paediatric population.

\section{METHODS}

\section{Sampling}

The data used in this study were obtained as part of a national survey on weight disorders conducted in 20112012 along with the fourth survey of a national schoolbased surveillance programme entitled the Childhood and Adolescence Surveillance and Prevention of Adult non-communicable disease (CASPIAN-IV) Study. We have previously described the methods of this study in detail $;{ }^{17}$ here, we briefly point to some details relevant to the current study.

Total sample size was calculated as 25000 students who were followed through multistage cluster sampling from urban and rural areas of 30 provinces of Iran. Stratification was performed according to the school grade (elementary, middle and high school) and living area (urban, rural). Eligible schools were stratified according to the information bank of the Ministry of Education. Students with a chronic disease, history of chronic medication consumption and those who were on a specific diet were not enrolled in this study.

\section{Physical examination}

A team of trained healthcare experts recorded information based on standard approved checklists and performed the examinations under standard protocols by using calibrated instruments. ${ }^{18}$ Weight was measured in light clothing to the nearest $0.1 \mathrm{~kg}$, and height was measured, without shoes, to the nearest $0.1 \mathrm{~cm}$ while the students were standing and with the shoulders in normal position. BMI was calculated as weight $(\mathrm{kg})$ divided by height squared $\left(\mathrm{m}^{2}\right) .{ }^{17} 18$

$\mathrm{NC}$ and WC were measured using a non-elastic tape to the nearest $0.1 \mathrm{~cm}$ over skin. NC measured by the tape underneath the Adam's apple contact with your skin at comfort position. WC detected midway between the iliac crest and the lowest rib in standing position. The maximum level of the hip without any pressure to the body surface to the nearest $0.5 \mathrm{~cm}$ was considered for measuring the hip circumference. We computed the waist-to-height ratio (WHtR) by dividing WC by height. Wrist circumference was measured with participants in a seated position from both wrists at distal to the prominences of the radial and ulnar and an average was taken. ${ }^{17} 18$

\section{Definition of terms}

Overweight was considered as BMI between the 85th and 94th centiles for age and sex, obesity as BMI equal to or greater than the sex-specific 95 th centile ${ }^{19}$; and abdominal obesity was defined as WHtR $>0.5$. $^{20}$

\section{Statistical analysis}

Results for continuous variables are shown as means and 95\% CI; categorical data are presented as a percentage. Differences among means were assessed by t-test. Pearson's correlation test was used to investigate the correlation between $\mathrm{NC}$ and other anthropometric measures. The receiver operator characteristic (ROC) curve analysis was used with an estimation of the variable's sensitivity and specificity in each gender stratified by age and age categories to assess the usual approach of specifying the cut-off values of NC for predicting overweight, obesity and abdominal obesity. The optimal cut-off point of NC for predicting overweight, general and abdominal obesity was defined as value, which represents the maximum sum of sensitivity and specificity in each gender stratified by age. ${ }^{21}$ The area under curve (AUC) was used as an indicator of overall ability of using the NC cut-off point to discriminate participants with or without overweight, general and abdominal obesity. AUC: 0.5 , AUC:0.5 to 0.65 and AUC: 0.65 to 1.0 were interpreted as equal to chance, moderately, highly accurate tests, respectively. ${ }^{21}$

Data were analysed using survey data analysis methods in the Stata software (Stata Statistical Software: Release 12. College Station, TX: Stata Corp LP. Package); $p<0.05$ was considered as statistically significant.

\section{Ethical concerns}

This study was conducted according to the declaration of Helsinki (Seoul, 2008). Ethical approval and any other required documents were given from the ethics committees and other relevant national and provincial regulatory organisations.

After complete explanation of the objectives and protocols for potential participants, they had the right to voluntarily participate in or withdraw from the study at any time. They were assured that their responses would remain anonymous and confidential. Written informed consent and oral assent were obtained from parents and students, respectively.

\section{RESULTS}

In total, 23043 school students (50.8\% boys) completed the study. The mean age of participants was 12.55 \pm 3.31 years without significant difference in terms of 
gender. Overall, $73.4 \%$ of participants were from urban areas and $26.6 \%$ from rural areas. Table 1 presents the mean $(95 \% \mathrm{CI})$ of anthropometric measures by age and sex. It shows that except for those aged 7-10 years (hip circumference), participants aged 10-14 years (height, BMI and hip circumference), as well as BMI in students aged 14-18 years, other measures were higher in boys than in girls.

The mean (SD) values of $\mathrm{NC}$ according to overweight, general and abdominal obesity are presented in table 2. Regardless of some aspects of exceptions in boys aged 8, 9, 17 and 18 years and girls aged 8 and 13 years, in both genders and in all age groups, the mean value of $\mathrm{NC}$ was significantly higher in those with overweight, general and abdominal obesity than in other participants.

Table 3 presents the correlation of NC with other anthropometric measures. In both genders and in the whole population studied, wrist circumference had a strong positive correlation with all anthropometric measures. On the other hand, modelling of different situations of associations showed that wrist circumference, in crude modelling and models adjusted for age, sex and living area, had a statistically significant positive correlation with overweight, general and abdominal obesity (table 4).

As presented in table 5, in all age groups and in both genders, NC performed relatively well in classifying participants to overweight (AUC: 0.67 to $0.75, \mathrm{p}<0.001$ ), general obesity (AUC: 0.81 to $0.85, \mathrm{p}<0.001$ ) and abdominal obesity (AUC: 0.73 to $0.78, \mathrm{p}<0.001$ ). Figures 1-3 show the ROC curves of NC for predicting overweight, general and abdominal obesity by age categories. The AUC was statistically lower in students aged 14-18 years than in those aged 7-10 and 10-14 years in those participants with overweight, general and abdominal obesity.

Table 6 presents the optimal cut-off point of NC to predict the presence of overweight, general and abdominal obesity with their corresponding specificity and sensitivity by gender.

\section{DISCUSSION}

Our findings show a significant association between NC and other anthropometric measurements of obesity in both genders of a national sample of the Iranian paediatric population. These evidence from a large population-based study, proposed that measuring of $\mathrm{NC}$ can be considered as an easy-to-use clinical marker and novel predictor of obesity.

Obesity/overweight become most arguably serious chronic health problem of children in most populations. ${ }^{16}$ Many studies have linked increased adverse health outcomes of childhood obesity even as short-term or long-term consequences. ${ }^{1}{ }^{2}{ }^{4}$ Controlling the epidemic of childhood obesity, detection, early prevention and treatment of childhood obesity are important priorities that need accurate diagnostic measures. ${ }^{5}$ Screening and monitoring tools must be low-cost, quick and easy to use, and generally acceptable to both patients and health practitioners. ${ }^{12} 14$

Some studies conducted in adults revealed the value of $\mathrm{NC}$ as a simple screening tool for identifying individuals with high $\mathrm{BMI}^{6}$ or confirmed the association of NC with other obesity indexes. ${ }^{14} 22$ However, limited experiences exist on the potential value of NC measurement as an index of obesity in the paediatric age group. ${ }^{142223}$ A limited number of studies exist on the reference data set of $\mathrm{NC}$ in children; the Canadian Health Measures Survey and Identification and Prevention of Dietary-and lifestyle-induced health Effects in Children and infants 'IDEFICS' have presented such data. ${ }^{24}{ }^{25}$ No previous large study has been conducted in the paediatric population of the Middle East and North Africa region.

$\mathrm{NC}$ can be used as an additional measure to screen children with overweight and obesity as suggested by Nafiu et al. ${ }^{12}$ Previous studies have found that NC, as a single marker of the upper body subcutaneous fat, seems a novel identity of pathogenic fat deposit. ${ }^{26}$

$\mathrm{NC}$ above the 50th centile is also proposed as a sensitive, valid new tool and a sensitive predictor of overweight/obesity (BMI $>85$ th centile) ${ }^{24}$ In one study, the cut-off values that showed higher sensitivity and specificity for $\mathrm{NC}$ to detect overweight in pre-pubertal and pubertal girls were 28.25 and $31.35 \mathrm{~cm}$, respectively. ${ }^{27}$ Some other investigations revealed a significant association between NC and increased risk of adverse health consequences of excess weight. ${ }^{25} 28$

In some previous research, NC has been highly correlated with WC and BMI all in all gender-age groups. Our findings are consistent with a study in Brazilian adolescents that found a high prevalence of elevated NC and its association with BMI, WC and body fat percentages. ${ }^{29}$ It suggested that upper body subcutaneous fat, obtained through NC measurement, could possibly represent greater metabolic risk than visceral fat. ${ }^{27} \mathrm{~A}$ study of Han children aged 7-12 years also showed a significant correlation of $\mathrm{NC}$ with age, BMI and $\mathrm{WC}$ in both genders. These findings proposed NC as a simple, inexpensive and accurate tool for identifying overweight and obese children. ${ }^{30}$

Validation of NC against WC and BMI, which is reported by Hatipoglu et al, ${ }^{14}$ showed that NC could be served as an easy way to determine overweight and obesity in children, indicating good correlation with cardiovascular risk factors. Consistent with this study, NC also performed well as an index of high BMI in young children and adolescents of both genders, in previous research. ${ }^{10} 12{ }^{14}$ Some studies also emphasised on predictive value of $\mathrm{NC}$ in detection of children who are at risk of central fat distribution, or even poor cardiovascular health. ${ }^{10143132}$ For instance, a cross-sectional study conducted among 1058 children aged 6-18 years revealed that the joint presence of wide $\mathrm{NC}$ and higher BMI was associated with a significantly higher prevalence 


\begin{tabular}{|c|c|c|c|c|c|c|c|c|}
\hline $\begin{array}{l}\text { Age (year)-sex } \\
\text { group }\end{array}$ & Weight (kg) & Height (cm) & BMI $\left(\mathbf{k g} / \mathbf{m}^{2}\right)$ & WC (cm) & Neck (cm) & WHR & WHtR & Hip (cm) \\
\hline \multicolumn{9}{|l|}{ Age group-boys } \\
\hline 7 & $\begin{array}{l}22.9 \text { (22.4 to } \\
23.4)\end{array}$ & $\begin{array}{l}127.2 \text { (122.8 to } \\
131.5)\end{array}$ & $\begin{array}{l}15.6 \text { (15.3 to } \\
15.9)\end{array}$ & $\begin{array}{l}56.6 \text { (55.9 to } \\
57.3)\end{array}$ & $\begin{array}{l}26.7 \text { (26.4 to } \\
27.0)\end{array}$ & $\begin{array}{l}0.869(0.860 \\
\text { to } 0.878)\end{array}$ & $\begin{array}{l}0.468 \text { (0.463 to } \\
0.474)\end{array}$ & $\begin{array}{l}65.4(64.6 \text { to } \\
66.1)\end{array}$ \\
\hline 8 & $\begin{array}{l}25.1 \text { ( } 24.6 \text { to } \\
25.5)\end{array}$ & $\begin{array}{l}124.7 \text { (123.9 to } \\
125.5)\end{array}$ & $\begin{array}{l}16.1 \text { (15.8 to } \\
16.5)\end{array}$ & $\begin{array}{l}57.6 \text { ( } 57.0 \text { to } \\
58.2)\end{array}$ & $\begin{array}{l}27.4 \text { ( } 27.0 \text { to } \\
27.9)\end{array}$ & $\begin{array}{l}0.859(0.853 \\
\text { to } 0.865)\end{array}$ & $\begin{array}{l}0.463(0.457 \text { to } \\
0.468)\end{array}$ & $\begin{array}{l}67.1(66.6 \text { to } \\
67.7)\end{array}$ \\
\hline 9 & $\begin{array}{l}27.5 \text { ( } 26.9 \text { to } \\
28.2)\end{array}$ & $\begin{array}{l}129.9(129.2 \text { to } \\
130.6)\end{array}$ & $\begin{array}{l}16.2 \text { (16.0 to } \\
16.5)\end{array}$ & $\begin{array}{l}59.3 \text { (58.6 to } \\
60.1)\end{array}$ & $\begin{array}{l}27.8 \text { (27.3 to } \\
28.2)\end{array}$ & $\begin{array}{l}0.852(0.843 \text { to } \\
0.860)\end{array}$ & $\begin{array}{l}0.456 \text { ( } 0.451 \text { to } \\
0.462)\end{array}$ & $\begin{array}{l}69.9(69.0 \text { to } \\
70.7)\end{array}$ \\
\hline 10 & $\begin{array}{l}31.3 \text { (30.5 to } \\
32.0)\end{array}$ & $\begin{array}{l}135.1 \text { (134.3 to } \\
135.9)\end{array}$ & $\begin{array}{l}17.1 \text { (16.8 to } \\
17.4)\end{array}$ & $\begin{array}{l}61.5 \text { (60.7 to } \\
62.3)\end{array}$ & $\begin{array}{l}28.2 \text { (28.0 to } \\
28.5)\end{array}$ & $\begin{array}{l}0.849(0.841 \text { to } \\
0.858)\end{array}$ & $\begin{array}{l}0.455(0.450 \text { to } \\
0.460)\end{array}$ & $\begin{array}{l}72.5 \text { (71.6 to } \\
73.3)\end{array}$ \\
\hline 11 & $\begin{array}{l}35.2 \text { (34.4 to } \\
36.1)\end{array}$ & $\begin{array}{l}140.4 \text { (139.8 to } \\
141.1)\end{array}$ & $\begin{array}{l}17.8 \text { (17.4 to } \\
18.0)\end{array}$ & $\begin{array}{l}64.2(63.5 \text { to } \\
65.0)\end{array}$ & $\begin{array}{l}29.0 \text { (28.8 to } \\
29.3 \text { ) }\end{array}$ & $\begin{array}{l}0.845 \text { (0.839 to } \\
0.851)\end{array}$ & $\begin{array}{l}0.457 \text { ( } 0.452 \text { to } \\
0.462)\end{array}$ & $\begin{array}{l}76.075 .2 \text { to } \\
76.9)\end{array}$ \\
\hline 12 & $\begin{array}{l}39.7 \text { (38.9 to } \\
40.6)\end{array}$ & $\begin{array}{l}145.5 \text { (144.8 to } \\
146.3)\end{array}$ & $\begin{array}{l}18.7 \text { (18.3 to } \\
19.0)\end{array}$ & $\begin{array}{l}67.5 \text { ( } 66.5 \text { to } \\
68.5)\end{array}$ & $\begin{array}{l}29.9 \text { (29.6 to } \\
30.0)\end{array}$ & $\begin{array}{l}0.850(0.841 \text { to } \\
0.860)\end{array}$ & $\begin{array}{l}0.463 \text { ( } 0.458 \text { to } \\
0.469)\end{array}$ & $\begin{array}{l}79.578 .6 \text { to } \\
80.5)\end{array}$ \\
\hline 13 & $\begin{array}{l}44.4 \text { (43.3 to } \\
45.4)\end{array}$ & $\begin{array}{l}151.5 \text { (150.5 to } \\
152.4)\end{array}$ & $\begin{array}{l}19.2 \text { (18.9 to } \\
19.5)\end{array}$ & $\begin{array}{l}70.3(69.2 \text { to } \\
71.5)\end{array}$ & $\begin{array}{l}31.0 \text { (30.5 to } \\
31.3 \text { ) }\end{array}$ & $\begin{array}{l}0.856(0.845 \text { to } \\
0.867)\end{array}$ & $\begin{array}{l}0.464 \text { ( } 0.458 \text { to } \\
0.470)\end{array}$ & $\begin{array}{l}82.481 .3 \text { to } \\
83.50)\end{array}$ \\
\hline 14 & $\begin{array}{l}49.6 \text { ( } 48.4 \text { to } \\
50.9)\end{array}$ & $\begin{array}{l}157.9 \text { (156.9 to } \\
158.9)\end{array}$ & $\begin{array}{l}19.8 \text { (19.4 to } \\
20.2)\end{array}$ & $\begin{array}{l}71.9 \text { (70.6 to } \\
73.0)\end{array}$ & $\begin{array}{l}31.5 \text { (31.2 to } \\
31.9)\end{array}$ & $\begin{array}{l}0.839 \text { ( } 0.830 \text { to } \\
0.849)\end{array}$ & $\begin{array}{l}0.455 \text { ( } 0.448 \text { to } \\
0.461)\end{array}$ & $\begin{array}{l}85.6 \text { ( } 84.4 \text { to } \\
86.7)\end{array}$ \\
\hline 15 & $\begin{array}{l}55.7 \text { ( } 54.5 \text { to } \\
56.9)\end{array}$ & $\begin{array}{l}164.6 \text { (163.7 to } \\
165.5)\end{array}$ & $\begin{array}{l}20.4 \text { (20.1 to } \\
20.8)\end{array}$ & $\begin{array}{l}73.6 \text { (72.4 to } \\
74.7)\end{array}$ & $\begin{array}{l}32.9 \text { (32.5 to } \\
33.3)\end{array}$ & $\begin{array}{l}0.834(0.826 \text { to } \\
0.841)\end{array}$ & $\begin{array}{l}0.446 \text { ( } 0.441 \text { to } \\
0.452)\end{array}$ & $\begin{array}{l}88.3(87.1 \text { to } \\
89.5)\end{array}$ \\
\hline 16 & $\begin{array}{l}60.7 \text { (59.5 to } \\
61.9)\end{array}$ & $\begin{array}{l}169.9(169.2 \text { to } \\
170.5)\end{array}$ & $\begin{array}{l}21.0 \text { (20.6 to } \\
21.4)\end{array}$ & $\begin{array}{l}75.8 \text { (74.8 to } \\
76.7)\end{array}$ & $\begin{array}{l}34.4 \text { (34.0 to } \\
34.8)\end{array}$ & $\begin{array}{l}0.831(0.824 \text { to } \\
0.839)\end{array}$ & $\begin{array}{l}0.446(0.441 \text { to } \\
0.451)\end{array}$ & $\begin{array}{l}91.3 \text { (90.3 to } \\
92.3)\end{array}$ \\
\hline 17 & $\begin{array}{l}64.6(63.4 \text { to } \\
65.9)\end{array}$ & $\begin{array}{l}172.4 \text { (171.5 to } \\
173.3)\end{array}$ & $\begin{array}{l}21.6 \text { ( } 21.3 \text { to } \\
22.0)\end{array}$ & $\begin{array}{l}76.9 \text { (75.8 to } \\
78.0)\end{array}$ & $\begin{array}{l}35.5 \text { (34.7 to } \\
36.2)\end{array}$ & $\begin{array}{l}0.837(0.829 \text { to } \\
0.845)\end{array}$ & $\begin{array}{l}0.446 \text { ( } 0.440 \text { to } \\
0.451)\end{array}$ & $\begin{array}{l}91.9 \text { (90.7 to } \\
93.1)\end{array}$ \\
\hline 18 & $\begin{array}{l}65.5 \text { (63.6 to } \\
67.3)\end{array}$ & $\begin{array}{l}173.2 \text { (172.0 to } \\
174.3)\end{array}$ & $\begin{array}{l}21.8 \text { (21.4 to } \\
22.3)\end{array}$ & $\begin{array}{l}77.3 \text { (75.7 to } \\
78.8)\end{array}$ & $\begin{array}{l}35.8 \text { (35.3 to } \\
36.3 \text { ) }\end{array}$ & $\begin{array}{l}0.845 \text { ( } 0.828 \text { to } \\
0.862)\end{array}$ & $\begin{array}{l}0.446(0.439 \text { to } \\
0.453)\end{array}$ & $\begin{array}{l}92.0 \text { (90.6 to } \\
93.5)\end{array}$ \\
\hline $7-10$ & $\begin{array}{l}26.6 \text { (26.1 to } \\
27.0)\end{array}$ & $\begin{array}{l}127.5 \text { (126.7 to } \\
128.1)\end{array}$ & $\begin{array}{l}16.2(16.0 \text { to } \\
16.5)\end{array}$ & $\begin{array}{l}58.7 \text { (58.2 to } \\
59.2)\end{array}$ & $\begin{array}{l}27.5 \text { (27.3 to } \\
27.8)\end{array}$ & $\begin{array}{l}0.857 \text { ( } 0.852 \text { to } \\
0.862)\end{array}$ & $\begin{array}{l}0.461(0.457 \text { to } \\
0.464)\end{array}$ & $\begin{array}{l}68.6(68.1 \text { to } \\
69.1)\end{array}$ \\
\hline $10-14$ & $\begin{array}{l}41.7 \text { ( } 40.9 \text { to } \\
42.5)\end{array}$ & $\begin{array}{l}148.2(147.3 \text { to } \\
149.0)\end{array}$ & $\begin{array}{l}18.7 \text { (18.5 to } \\
18.9)\end{array}$ & $\begin{array}{l}68.2(67.5 \text { to } \\
68.9)\end{array}$ & $\begin{array}{l}30.2 \text { (30.0 to } \\
30.4)\end{array}$ & $\begin{array}{l}0.848(0.842 \text { to } \\
0.854)\end{array}$ & $\begin{array}{l}0.460(0.457 \text { to } \\
0.463)\end{array}$ & $\begin{array}{l}80.55 \text { (79.8 to } \\
81.3)\end{array}$ \\
\hline $14-18$ & $\begin{array}{l}61.2(60.2 \text { to } \\
62.1)\end{array}$ & $\begin{array}{l}169.6 \text { (169.0 to } \\
170.3)\end{array}$ & $\begin{array}{l}21.1 \text { (20.9 to } \\
21.4)\end{array}$ & $\begin{array}{l}75.7 \text { (74.9 to } \\
76.5)\end{array}$ & $\begin{array}{l}34.5 \text { (34.2 to } \\
34.8)\end{array}$ & $\begin{array}{l}0.836 \text { ( } 0.830 \text { to } \\
0.842)\end{array}$ & $\begin{array}{l}0.452 \text { ( } 0.449 \text { to } \\
0.456)\end{array}$ & $\begin{array}{l}90.8 \text { (89.9 to } \\
91.6)\end{array}$ \\
\hline \multicolumn{9}{|l|}{ Age group_-girls } \\
\hline 7 & $\begin{array}{l}22.3 \text { ( } 21.7 \text { to } \\
22.9)\end{array}$ & $\begin{array}{l}119.8 \text { (118.8 to } \\
120.8)\end{array}$ & $\begin{array}{l}15.6 \text { (15.2 to } \\
16.0)\end{array}$ & $\begin{array}{l}54.9 \text { (54.0 to } \\
55.8)\end{array}$ & $\begin{array}{l}25.8 \text { ( } 25.5 \text { to } \\
26.2)\end{array}$ & $\begin{array}{l}0.851(0.842 \\
\text { to.860) }\end{array}$ & $\begin{array}{l}0.460(0.452 \\
\text { to. } 468)\end{array}$ & $\begin{array}{l}64.8(63.7 \text { to } \\
66.0)\end{array}$ \\
\hline 8 & $\begin{array}{l}23.8 \text { (23.3 to } \\
24.3)\end{array}$ & $\begin{array}{l}122.8 \text { (121.8 to } \\
123.8)\end{array}$ & $\begin{array}{l}15.9 \text { (15.4 to } \\
16.3)\end{array}$ & $\begin{array}{l}55.5 \text { (54.6 to } \\
56.3)\end{array}$ & $\begin{array}{l}26.7 \text { (26.1 to } \\
27.4)\end{array}$ & $\begin{array}{l}0.848 \text { ( } 0.839 \text { to } \\
0.858)\end{array}$ & $\begin{array}{l}0.453(0.445 \text { to } \\
0.461)\end{array}$ & $\begin{array}{l}65.8 \text { (64.8 to } \\
66.9)\end{array}$ \\
\hline 9 & $\begin{array}{l}27.5 \text { ( } 26.9 \text { to } \\
28.1)\end{array}$ & $\begin{array}{l}129.4 \text { (128.7 to } \\
130.0)\end{array}$ & $\begin{array}{l}16.3 \text { (16.1 to } \\
16.6)\end{array}$ & $\begin{array}{l}58.6 \text { ( } 57.8 \text { to } \\
59.3)\end{array}$ & $\begin{array}{l}27.4 \text { ( } 27.0 \text { to } \\
27.7)\end{array}$ & $\begin{array}{l}0.841 \text { ( } 0.832 \text { to } \\
0.849)\end{array}$ & $\begin{array}{l}0.453 \text { ( } 0.448 \text { to } \\
0.458)\end{array}$ & $\begin{array}{l}70.0 \text { (69.2 to } \\
70.9)\end{array}$ \\
\hline
\end{tabular}




\begin{tabular}{|c|c|c|c|c|c|c|c|c|}
\hline $\begin{array}{l}\text { Age (year)-sex } \\
\text { group }\end{array}$ & Weight (kg) & Height (cm) & BMI $\left(\mathrm{kg} / \mathrm{m}^{2}\right)$ & WC (cm) & Neck (cm) & WHR & WHtR & Hip (cm) \\
\hline 10 & $\begin{array}{l}31.2 \text { ( } 30.5 \text { to } \\
32.0)\end{array}$ & $\begin{array}{l}135.2 \text { (134.4 to } \\
135.9)\end{array}$ & $\begin{array}{l}17.0(16.7 \text { to } \\
17.3)\end{array}$ & $\begin{array}{l}61.1 \text { ( } 60.3 \text { to } \\
61.9)\end{array}$ & $\begin{array}{l}28.0(27.7 \text { to } \\
28.4)\end{array}$ & $\begin{array}{l}0.831 \text { ( } 0.823 \text { to } \\
0.840)\end{array}$ & $\begin{array}{l}0.452 \text { (0.446 to } \\
0.457)\end{array}$ & $\begin{array}{l}73.7 \text { (72.7 to } \\
74.7)\end{array}$ \\
\hline 11 & $\begin{array}{l}35.0 \text { ( } 34.0 \text { to } \\
35.9)\end{array}$ & $\begin{array}{l}140.7 \text { (139.7 to } \\
141.7)\end{array}$ & $\begin{array}{l}17.5 \text { (17.2 to } \\
17.9)\end{array}$ & $\begin{array}{l}62.9(62.0 \text { to } \\
63.7)\end{array}$ & $\begin{array}{l}28.6 \text { ( } 28.3 \text { to } \\
29.0)\end{array}$ & $\begin{array}{l}0.826(0.817 \text { to } \\
0.834)\end{array}$ & $\begin{array}{l}0.446 \text { ( } 0.441 \text { to } \\
0.452)\end{array}$ & $\begin{array}{l}76.4 \text { (75.3 to } \\
77.5)\end{array}$ \\
\hline 12 & $\begin{array}{l}39.9 \text { (38.9 to } \\
40.9)\end{array}$ & $\begin{array}{l}147.1 \text { ( } 146.2 \text { to } \\
148.0)\end{array}$ & $\begin{array}{l}18.3(18.0 \text { to } \\
18.7)\end{array}$ & $\begin{array}{l}65.4(64.6 \text { to } \\
66.3)\end{array}$ & $\begin{array}{l}29.6 \text { ( } 29.2 \text { to } \\
30.1)\end{array}$ & $\begin{array}{l}0.811(0.804 \text { to } \\
0.818)\end{array}$ & $\begin{array}{l}0.444 \text { ( } 0.439 \text { to } \\
0.449)\end{array}$ & $\begin{array}{l}80.8 \text { (79.8 to } \\
81.8)\end{array}$ \\
\hline 13 & $\begin{array}{l}46.4 \text { ( } 45.2 \text { to } \\
47.5)\end{array}$ & $\begin{array}{l}153.2(152.4 \text { to } \\
153.9)\end{array}$ & $\begin{array}{l}19.7 \text { (19.2 to } \\
20.1)\end{array}$ & $\begin{array}{l}69.0 \text { ( } 68.0 \text { to } \\
70.0)\end{array}$ & $\begin{array}{l}31.0 \text { (30.5 to } \\
31.4)\end{array}$ & $\begin{array}{l}0.802(0.794 \text { to } \\
0.809)\end{array}$ & $\begin{array}{l}0.450(0.444 \text { to } \\
0.456)\end{array}$ & $\begin{array}{l}86.2 \text { (85.3 to } \\
87.1)\end{array}$ \\
\hline 14 & $\begin{array}{l}50.1 \text { ( } 49.1 \text { to } \\
51.2)\end{array}$ & $\begin{array}{l}156.2 \text { (155.7 to } \\
156.8)\end{array}$ & $\begin{array}{l}20.6 \text { (20.1 to } \\
21.0)\end{array}$ & $\begin{array}{l}69.6 \text { (68.9 to } \\
70.4)\end{array}$ & $\begin{array}{l}31.2 \text { (30.9 to } \\
31.5)\end{array}$ & $\begin{array}{l}0.789 \text { ( } 0.782 \text { to } \\
0.796)\end{array}$ & $\begin{array}{l}0.446 \text { ( } 0.441 \text { to } \\
0.451)\end{array}$ & $\begin{array}{l}88.3 \text { ( } 87.5 \text { to } \\
89.0)\end{array}$ \\
\hline 15 & $\begin{array}{l}53.0(52.4 \text { to } \\
53.8)\end{array}$ & $\begin{array}{l}158.8 \text { (158.2 to } \\
159.3)\end{array}$ & $\begin{array}{l}21.0(20.7 \text { to } \\
21.3)\end{array}$ & $\begin{array}{l}71.1 \text { ( } 70.3 \text { to } \\
72.0)\end{array}$ & $\begin{array}{l}31.9 \text { (31.5 to } \\
32.2)\end{array}$ & $\begin{array}{l}0.786(0.777 \text { to } \\
0.794)\end{array}$ & $\begin{array}{l}0.448 \text { (0.443 to } \\
0.453)\end{array}$ & $\begin{array}{l}90.8 \text { (90.0 to } \\
91.6)\end{array}$ \\
\hline 16 & $\begin{array}{l}54.8 \text { (52.0 to } \\
55.5)\end{array}$ & $\begin{array}{l}160.0 \text { (159.5 to } \\
160.5)\end{array}$ & $\begin{array}{l}21.4(21.1 \text { to } \\
21.6)\end{array}$ & $\begin{array}{l}72.3(71.5 \text { to } \\
73.0)\end{array}$ & $\begin{array}{l}32.2 \text { (31.9 to } \\
32.5)\end{array}$ & $\begin{array}{l}0.783 \text { ( } 0.776 \text { to } \\
0.789)\end{array}$ & $\begin{array}{l}0.452 \text { ( } 0.447 \text { to } \\
0.456)\end{array}$ & $\begin{array}{l}92.6 \text { (91.9 to } \\
93.3)\end{array}$ \\
\hline 17 & $\begin{array}{l}55.3(54.4 \text { to } \\
56.1)\end{array}$ & $\begin{array}{l}159.8 \text { (159.1 to } \\
160.3)\end{array}$ & $\begin{array}{l}21.7 \text { ( } 21.4 \text { to } \\
22.0)\end{array}$ & $\begin{array}{l}73.0(72.2 \text { to } \\
73.9)\end{array}$ & $\begin{array}{l}32.5 \text { (32.0 to } \\
32.9)\end{array}$ & $\begin{array}{l}0.784 \text { ( } 0.777 \text { to } \\
0.791)\end{array}$ & $\begin{array}{l}0.457 \text { ( } 0.452 \text { to } \\
0.463)\end{array}$ & $\begin{array}{l}93.2 \text { (92.4 to } \\
94.1)\end{array}$ \\
\hline 18 & $\begin{array}{l}56.1 \text { (55.0 to } \\
57.3)\end{array}$ & $\begin{array}{l}159.9(159.2 \text { to } \\
160.5)\end{array}$ & $\begin{array}{l}22.0(21.5 \text { to } \\
22.3)\end{array}$ & $\begin{array}{l}72.7 \text { ( } 71.6 \text { to } \\
73.9)\end{array}$ & $\begin{array}{l}32.7 \text { ( } 32.0 \text { to } \\
33.3)\end{array}$ & $\begin{array}{l}0.775(0.764 \text { to } \\
0.786)\end{array}$ & $\begin{array}{l}0.455 \text { ( } 0.448 \text { to } \\
0.462)\end{array}$ & $\begin{array}{l}94.1 \text { (92.9 to } \\
95.3)\end{array}$ \\
\hline $7-10$ & $\begin{array}{l}26.4 \text { ( } 25.9 \text { to } \\
27.0)\end{array}$ & $\begin{array}{l}127.2 \text { (126.4 to } \\
128.0)\end{array}$ & $\begin{array}{l}16.2(15.9 \text { to } \\
16.4)\end{array}$ & $\begin{array}{l}57.7 \text { ( } 57.1 \text { to } \\
58.2)\end{array}$ & $\begin{array}{l}27.1 \text { ( } 26.8 \text { to } \\
27.4)\end{array}$ & $\begin{array}{l}0.842(0.837 \text { to } \\
0.848)\end{array}$ & $\begin{array}{l}0.454 \text { ( } 0.450 \text { to } \\
0.458)\end{array}$ & $\begin{array}{l}68.8(68.0 \text { to } \\
69.6)\end{array}$ \\
\hline $10-14$ & $\begin{array}{l}43.0(42.2 \text { to } \\
43.9)\end{array}$ & $\begin{array}{l}149.5 \text { (148.7 to } \\
150.3)\end{array}$ & $\begin{array}{l}19.0 \text { (18.8 to } \\
19.3)\end{array}$ & $\begin{array}{l}66.8 \text { (66.3 to } \\
67.4)\end{array}$ & $\begin{array}{l}30.2 \text { (29.9 to } \\
30.4)\end{array}$ & $\begin{array}{l}0.806 \text { ( } 0.802 \text { to } \\
0.811)\end{array}$ & $\begin{array}{l}0.447 \text { ( } 0.444 \text { to } \\
0.450)\end{array}$ & $\begin{array}{l}83.1 \text { ( } 82.3 \text { to } \\
83.84)\end{array}$ \\
\hline $14-18$ & $\begin{array}{l}54.6 \text { ( } 54.0 \text { to } \\
55.0)\end{array}$ & $\begin{array}{l}159.5 \text { (159.2 to } \\
159.9)\end{array}$ & $\begin{array}{l}21.4(21.2 \text { to } \\
21.6)\end{array}$ & $\begin{array}{l}72.2 \text { ( } 71.6 \text { to } \\
72.7)\end{array}$ & $\begin{array}{l}32.2 \text { ( } 32.0 \text { to } \\
32.5)\end{array}$ & $\begin{array}{l}0.782 \text { ( } 0.778 \text { to } \\
0.787)\end{array}$ & $\begin{array}{l}0.452 \text { ( } 0.449 \text { to } \\
0.456)\end{array}$ & $\begin{array}{l}92.5 \text { (91.9 to } \\
93.0)\end{array}$ \\
\hline
\end{tabular}


Table 2 Mean (SD) of neck circumference according to overweight, general and abdominal obesity in Iranian children and adolescents by age and sex: the CASPIAN-IV Study

\begin{tabular}{|c|c|c|c|c|c|c|c|c|c|}
\hline \multirow[t]{2}{*}{ Age (year)-sex group } & \multicolumn{3}{|l|}{ Overweight } & \multicolumn{3}{|l|}{ General obesity } & \multicolumn{3}{|l|}{ Abdominal obesity } \\
\hline & Yes & No & p Value & $\overline{\text { Yes }}$ & No & p Value & $\overline{\text { Yes }}$ & No & p Value \\
\hline \multicolumn{10}{|l|}{ Age group-boys } \\
\hline 7 & $28.2(27.7,28.7)$ & $26.5(26.3,26.7)$ & $<0.001$ & $28.7(28.1,29.4)$ & $26.5(26.3,26.7)$ & $<0.001$ & $28.0(27.4,28.6)$ & $26.4(26.2,26.6)$ & $<0.001$ \\
\hline 8 & $28.6(28.2,29.0)$ & $27.3(26.8,27.8)$ & 0.06 & $28.8(28.2,29.5)$ & $27.3(26.8,27.7)$ & 0.04 & $28.6(28.2,28.9)$ & $27.2(26.6,27.7)$ & 0.01 \\
\hline 9 & $28.8(28.1,29.4)$ & $27.7(27.3,28.0)$ & 0.05 & $31.1(29.4,32.7)$ & $27.5(27.2,27.8)$ & $<0.001$ & $29.9(28.9,31.1)$ & $27.3(27.0,27.7)$ & $<0.001$ \\
\hline 10 & $29.9(29.4,30.3)$ & $28.0(27.8,28.3)$ & $<0.001$ & $30.9(30.1,31.6)$ & $28.0(27.7,28.2)$ & $<0.001$ & $30.3(29.8,30.8)$ & $27.8(27.6,28.0)$ & $<0.001$ \\
\hline 11 & $30.6(30.3,31.0)$ & $28.8(28.6,28.9)$ & $<0.001$ & $33.4(32.7,34.0)$ & $28.5(28.4,28.7)$ & $<0.001$ & $31.7(31.3,32.2)$ & $28.4(28.2,28.5)$ & $<0.001$ \\
\hline 12 & $31.6(31.3,32.0)$ & $29.5(29.3,29.7)$ & $<0.001$ & $33.4(32.9,34.0)$ & $29.4(29.2,29.6)$ & $<0.001$ & $32.3(31.9,32.7)$ & $29.0(28.9,29.2)$ & $<0.001$ \\
\hline 13 & $33.1(32.0,34.1)$ & $30.5(30.2,30.8)$ & $<0.001$ & $34.2(33.2,35.3)$ & $30.6(30.3,30.9)$ & $<0.001$ & $33.2(32.4,34.0)$ & $30.1(29.8,30.4)$ & $<0.001$ \\
\hline 14 & $32.9(32.2,33.5)$ & $31.4(31.1,31.6)$ & $<0.001$ & $34.6(33.7,35.5)$ & $31.3(31.1,31.6)$ & $<0.001$ & $33.3(32.8,33.8)$ & $31.0(30.8,31.2)$ & $<0.001$ \\
\hline 15 & $34.6(34.1,35.1)$ & $32.6(32.3,33.0)$ & $<0.001$ & $37.0(36.1,37.8)$ & $32.6(32.3,33.0)$ & $<0.001$ & $35.5(35.0,36.0)$ & $32.4(32.0,32.7)$ & $<0.001$ \\
\hline 16 & $37.0(36.0,38.1)$ & $33.9(33.7,34.1)$ & $<0.001$ & $39.0(38.1,39.9)$ & $34.1(33.9,34.3)$ & $<0.001$ & $37.4(36.7,38.1)$ & $33.7(33.5,34.0)$ & $<0.001$ \\
\hline 17 & $36.5(35.7,37.3)$ & $35.3(34.5,36.1)$ & 0.26 & $39.1(38.4,39.8)$ & $35.2(34.4,35.9)$ & $<0.001$ & $38.5(37.5,39.5)$ & $34.9(34.1,35.7)$ & $<0.001$ \\
\hline 18 & $36.9(35.8,37.9)$ & $35.7(35.3,36.1)$ & 0.04 & $39.3(38.3,40.4)$ & $35.6(35.3,36.0)$ & $<0.001$ & $38.5(37.5,39.4)$ & $35.3(34.9,35.7)$ & $<0.001$ \\
\hline $7-10$ & $28.8(28.6,29.1)$ & $27.4(27.2,27.6)$ & $<0.001$ & $29.8(29.3,30.3)$ & $27.3(27.1,27.5)$ & $<0.001$ & $29.1(28.8,29.5)$ & $27.2(27.0,27.4)$ & $<0.001$ \\
\hline $10-14$ & $32.0(31.6,32.4)$ & $29.9(29.8,30.0)$ & $<0.001$ & $33.8(33.4,34.2)$ & $29.9(29.7,30.0)$ & $<0.001$ & $32.6(32.3,32.9)$ & $29.5(29.4,29.6)$ & $<0.001$ \\
\hline $14-18$ & $36.20(35.7,36.6)$ & $34.3(34.0,34.5)$ & $<0.001$ & $38.5(38.1,39.0)$ & $34.3(34.0,34.5)$ & $<0.001$ & $37.3(36.9,37.70$ & $34.0(33.7,34.2)$ & $<0.001$ \\
\hline \multicolumn{10}{|l|}{ Age group-girls } \\
\hline 7 & $26.7(26.1,27.4)$ & $25.7(25.5,26.0)$ & $<0.001$ & $28.9(27.9,29.9)$ & $25.7(25.5,25.9)$ & $<0.001$ & $26.7(26.1,27.3)$ & $25.7(25.5,25.9)$ & $<0.001$ \\
\hline 8 & $27.2(26.5,27.9)$ & $26.7(26.1,27.3)$ & 0.62 & $29.4(25.6,33.3)$ & $26.6(26.0,27.1)$ & 0.01 & $29.1(27.6,30.6)$ & $26.3(25.7,26.9)$ & $<0.001$ \\
\hline 9 & $29.9(28.5,31.4)$ & $27.0(26.8,27.2)$ & $<0.001$ & $29.6(28.6,30.6)$ & $27.3(27.0,27.5)$ & $<0.001$ & $29.8(28.6,31.0)$ & $26.9(26.7,27.1)$ & $<0.001$ \\
\hline 10 & $29.7(29.1,30.4)$ & $27.7(27.4,28.1)$ & $<0.001$ & $31.8(31.1,32.4)$ & $27.7(27.4,28.0)$ & $<0.001$ & $30.2(29.6,30.8$ & $27.5(27.2,27.9)$ & $<0.001$ \\
\hline 11 & $31.3(30.0,32.6)$ & $28.2(28.0,28.5)$ & $<0.001$ & $32.5(31.4,33.6)$ & $28.5(28.2,28.7)$ & $<0.001$ & $31.7(30.4,33.1)$ & $28.2(28.0,28.4)$ & $<0.001$ \\
\hline 12 & $31.3(30.8,31.8)$ & $29.4(29.0,29.8)$ & $<0.001$ & $33.8(30.3,37.2)$ & $29.4(29.1,29.7)$ & $<0.001$ & $32.1(30.8,33.4)$ & $29.2(28.9,29.5)$ & $<0.001$ \\
\hline 13 & $32.4(31.9,32.9)$ & $30.7(30.3,31.2)$ & 0.002 & $33.6(32.8,34.3)$ & $30.8(30.4,31.2)$ & 0.002 & $33.8(32.5,35.1)$ & $30.4(30.0,30.7)$ & 0.002 \\
\hline 14 & $33.4(32.6,34.3)$ & $30.9(30.7,31.1)$ & $<0.001$ & $34.7(34.1,35.4)$ & $30.9(30.7,31.1)$ & $<0.001$ & $34.0(33.2,34.8)$ & $30.7(30.5,30.9)$ & $<0.001$ \\
\hline 15 & $33.4(32.9,33.8)$ & $31.6(31.3,31.9)$ & $<0.001$ & $36.2(34.3,38.0)$ & $31.6(31.4,31.9)$ & $<0.001$ & $34.4(33.6,35.1)$ & $31.4(31.2,31.6)$ & $<0.001$ \\
\hline 16 & $34.2(33.6,34.9)$ & $31.8(31.6,32.0)$ & $<0.001$ & $36.4(35.7,37.1)$ & $32.0(31.8,32.2)$ & $<0.001$ & $35.0(34.3,35.7)$ & $31.6(31.4,31.8)$ & $<0.001$ \\
\hline 17 & $34.3(33.8,34.8)$ & $32.2(31.9,32.6)$ & $<0.001$ & $36.1(33.0,39.2)$ & $32.3(32.0,32.6)$ & $<0.001$ & $35.1(33.7) 36.5$, & $31.8(31.6,32.0)$ & $<0.001$ \\
\hline 18 & $35.16(33.9,36.4)$ & $32.3(32.0,32.6)$ & $<0.001$ & $35.2(34.2,36.3)$ & $32.5(32.2,32.9)$ & $<0.001$ & $34.8(33.84,35.7)$ & $32.1(31.8,32.47)$ & $<0.001$ \\
\hline $7-10$ & $28.8(28.2,29.3)$ & $26.9(26.6,27.1)$ & $<0.001$ & $30.1(29.0,31.3)$ & $26.9(26.7,27.1)$ & $<0.001$ & $29.3(28.7,29.9)$ & $26.7(26.5,26.9)$ & $<0.001$ \\
\hline $10-14$ & $32.1(31.8,32.5)$ & $29.9(29.7,30.0)$ & $<0.001$ & $33.8(32.9,34.6)$ & $29.9(29.8,30.1)$ & $<0.001$ & $33.0(32.4,33.7)$ & $29.7(29.5,29.8)$ & $<0.001$ \\
\hline $14-18$ & $34.1(33.8,34.5)$ & $32.0(31.8,32.1)$ & $<0.001$ & $36.0(35.1,37.0)$ & $32.0(31.9,32.2)$ & $<0.001$ & $34.8(34.3,35.3)$ & $31.7(31.6,31.8)$ & $<0.001$ \\
\hline
\end{tabular}


Table 3 Pearson's correlation between neck circumference and anthropometric characteristics in Iranian children and adolescents by sex: the CASPIAN-IV study

\begin{tabular}{|c|c|c|c|c|c|c|}
\hline \multirow[b]{4}{*}{ Anthropometric measures } & \multicolumn{6}{|c|}{ Neck circumference (cm) } \\
\hline & \multicolumn{6}{|l|}{ Sex } \\
\hline & \multicolumn{2}{|l|}{ Boys } & \multicolumn{2}{|l|}{ Girls } & \multicolumn{2}{|l|}{ Total } \\
\hline & $\begin{array}{l}\text { Pearson's } \\
\text { correlation }\end{array}$ & p Value & $\begin{array}{l}\text { Pearson's } \\
\text { correlation }\end{array}$ & p Value & $\begin{array}{l}\text { Pearson } \\
\text { correlation }\end{array}$ & p Value \\
\hline Weight (cm) & $0.546^{\star}$ & $<0.001$ & $0.481^{*}$ & $<0.001$ & $0.519^{*}$ & $<0.001$ \\
\hline Height (cm) & $0.506^{\star}$ & $<0.001$ & $0.416^{\star}$ & $<0.001$ & $0.470^{*}$ & $<0.001$ \\
\hline BMI $\left(\mathrm{kg} / \mathrm{m}^{2}\right) \dagger$ & $0.389^{\star}$ & $<0.001$ & $0.387^{*}$ & $<0.001$ & $0.384^{*}$ & $<0.001$ \\
\hline WC $(\mathrm{cm})^{*}$ & $0.491^{*}$ & $<0.001$ & $0.456^{\star}$ & $<0.001$ & $0.479^{*}$ & $<0.001$ \\
\hline WHR & $0.035^{\star}$ & $<0.001$ & -0.020 & $<0.001$ & $0.023^{*}$ & $<0.001$ \\
\hline WHtR§ & $0.156^{\star}$ & $<0.001$ & $0.222^{*}$ & $<0.001$ & $0.188^{\star}$ & $<0.001$ \\
\hline \multirow[t]{3}{*}{ Hip (cm) } & $0.505^{\star}$ & $<0.001$ & $0.464^{\star}$ & $<0.001$ & $0.478^{\star}$ & $<0.001$ \\
\hline & \multicolumn{6}{|c|}{ Age group (year) } \\
\hline & $7-10$ & & $11-14$ & & $15-18$ & \\
\hline Weight $(\mathrm{cm})$ & $0.232^{\star}$ & $<0.001$ & $0.451^{*}$ & $<0.001$ & $0.366^{\star}$ & $<0.001$ \\
\hline Height $(\mathrm{cm})$ & $0.183^{\star}$ & $<0.001$ & $0.334^{\star}$ & $<0.001$ & $0.259^{\star}$ & $<0.001$ \\
\hline BMI $\left(\mathrm{kg} / \mathrm{m}^{2}\right) \dagger$ & $0.146 \dagger$ & $<0.001$ & $0.350^{*}$ & $<0.001$ & $0.264^{*}$ & $<0.001$ \\
\hline WC $(\mathrm{cm})^{*}$ & $0.258^{\star}$ & $<0.001$ & $0.433^{*}$ & $<0.001$ & $0.335^{\star}$ & $<0.001$ \\
\hline WHR $\ddagger$ & 0.018 & $<0.001$ & $0.084^{\star}$ & $<0.001$ & $0.139^{\star}$ & $<0.001$ \\
\hline WHtR§ & $0.163 \dagger$ & $<0.001$ & $0.302^{*}$ & $<0.001$ & $0.238^{\star}$ & $<0.001$ \\
\hline Hip (cm) & $0.253^{*}$ & $<0.001$ & $0.407^{\star}$ & $<0.001$ & $0.260^{*}$ & $<0.001$ \\
\hline \multicolumn{7}{|l|}{$\begin{array}{l}\text { *Waist circumference. } \\
\text { †BMI. } \\
\text { †WHtR. } \\
\text { \$WHR. } \\
\text { BMI, body mass index }\end{array}$} \\
\hline
\end{tabular}

Table 4 Association of neck circumference with overweight, general and abdominal obesity in a logistic regression model: the CASPIAN study

\begin{tabular}{lllll}
\hline & Model & $\begin{array}{l}\text { Overweight } \\
\text { OR }(\mathbf{9 5 \%} \mathbf{~ C l})\end{array}$ & $\begin{array}{l}\text { General obesity } \\
\text { OR }(\mathbf{9 5 \%} \mathbf{~ C l})\end{array}$ & $\begin{array}{l}\text { Abdominal obesity } \\
\text { OR (95\% } \mathbf{C l})\end{array}$ \\
\hline Neck circumference $(\mathrm{cm})$ & Model I & $1.06(1.05 \text { to } 1.07)^{*}$ & $1.07(1.06 \text { to } 1.08)^{*}$ & $1.12(1.11 \text { to } 1.13)^{*}$ \\
& Model II & $1.07(1.06 \text { to } 1.08)^{*}$ & $1.10(1.08 \text { to } 1.11)^{*}$ & $1.20(1.18 \text { to } 1.21)^{*}$ \\
\hline
\end{tabular}

Model I: without adjustment.

Model II: adjusted for age, sex and living area.

*Statistically significant.

of elevated blood pressure (BP). ${ }^{33}$ Another study in 324 Greek children aged 9-13 years found that NC was associated with most cardiovascular disease (CVD) risk factors. The study showed that the association of NC and CVD was comparable to the observed relations of BMI z-score, WC, hip circumference (HC), waist-to-hip ratio (WHR) and $\mathrm{WHtR}{ }^{34}$ In line with these studies, NC measurement was indicated as a reliable anthropometric index to predict children with cardiometabolic disease. ${ }^{32}$

NC measurement is a reliable and inexpensive index, with easier measurement than other indexes of adiposity, that is, WC and BMI. ${ }^{62}{ }^{35}$ In addition, measurement of NC may be used as a predictor tool for obstructive sleep apnoea, especially in obese children. ${ }^{23} 36$ Furthermore, neck-to-waist ratio, as an index of body fat distribution, could predict obstructive sleep apnoea in older children and adolescents, especially in those who are overweight and/or obese. ${ }^{28}$

This study was the first of its kind to find the association of NC and anthropometric indices in the paediatrics in Iran. A nationwide survey and large sample size could serve the data representative in Iranian children and adolescents. These findings might be practical for health policymakers. Methodologically, using the best updated fitted methods on almost gathered qualified data led to more accurate estimations.

However, the study had some limitations that should be considered in interpreting the data. First, the crosssectional nature of the study, to some extent, limits its interpretation as to causality of associations. 
Table 5 Area under curve (AUC) for detection of overweight, general and abdominal obesity based on the neck circumference in Iranian children and adolescents by sex and age: the CASPIAN-IV study

\begin{tabular}{|c|c|c|c|c|c|c|c|c|c|}
\hline \multirow[b]{2}{*}{ Age (year) sex group } & \multicolumn{3}{|c|}{ Overweight } & \multicolumn{3}{|c|}{ General obesity } & \multicolumn{3}{|c|}{ Abdominal obesity } \\
\hline & $\begin{array}{l}\text { AUC } \\
(95 \% \mathrm{Cl})\end{array}$ & SE & p Value & $\begin{array}{l}\text { AUC } \\
(95 \% \mathrm{Cl})\end{array}$ & SE & p Value & $\begin{array}{l}\text { AUC } \\
(95 \% \mathrm{CI})\end{array}$ & SE & p Value \\
\hline \multicolumn{10}{|l|}{ Age group-boys } \\
\hline 7 & 0.774 & 0.024 & $<0.001$ & 0.788 & 0.037 & $<0.001$ & 0.682 & 0.026 & $<0.001$ \\
\hline 8 & 0.739 & 0.021 & $<0.001$ & 0.715 & 0.031 & $<0.001$ & 0.719 & 0.020 & $<0.001$ \\
\hline 9 & 0.713 & 0.030 & $<0.001$ & 0.804 & 0.036 & $<0.001$ & 0.745 & 0.025 & $<0.001$ \\
\hline 10 & 0.753 & 0.024 & $<0.001$ & 0.817 & 0.034 & $<0.001$ & 0.799 & 0.024 & $<0.001$ \\
\hline 11 & 0.762 & 0.018 & $<0.001$ & 0.908 & 0.019 & $<0.001$ & 0.838 & 0.018 & $<0.001$ \\
\hline 12 & 0.764 & 0.018 & $<0.001$ & 0.866 & 0.020 & $<0.001$ & 0.830 & 0.015 & $<0.001$ \\
\hline 13 & 0.761 & 0.019 & $<0.001$ & 0.824 & 0.028 & $<0.001$ & 0.790 & 0.017 & $<0.001$ \\
\hline 14 & 0.691 & 0.030 & $<0.001$ & 0.787 & 0.038 & $<0.001$ & 0.730 & 0.022 & $<0.001$ \\
\hline 15 & 0.714 & 0.023 & $<0.001$ & 0.853 & 0.030 & $<0.001$ & 0.785 & 0.021 & $<0.001$ \\
\hline 16 & 0.761 & 0.018 & $<0.001$ & 0.866 & 0.028 & $<0.001$ & 0.801 & 0.018 & $<0.001$ \\
\hline 17 & 0.676 & 0.026 & $<0.001$ & 0.855 & 0.026 & $<0.001$ & 0.779 & 0.021 & $<0.001$ \\
\hline 18 & 0.681 & 0.035 & $<0.001$ & 0.824 & 0.037 & $<0.001$ & 0.768 & 0.024 & $<0.001$ \\
\hline $7-10$ & 0.730 & 0.013 & $<0.001$ & 0.763 & 0.018 & $<0.001$ & 0.718 & 0.012 & $<0.001$ \\
\hline $10-14$ & 0.725 & 0.010 & $<0.001$ & 0.837 & 0.012 & $<0.001$ & 0.796 & 0.009 & $<0.001$ \\
\hline $14-18$ & 0.693 & 0.012 & $<0.001$ & 0.843 & 0.015 & $<0.001$ & 0.772 & 0.011 & $<0.001$ \\
\hline \multicolumn{10}{|l|}{ Age group-girls } \\
\hline 7 & 0.627 & 0.040 & $<0.001$ & 0.848 & 0.038 & $<0.001$ & 0.632 & 0.036 & $<0.001$ \\
\hline 8 & 0.676 & 0.033 & $<0.001$ & 0.722 & 0.045 & $<0.001$ & 0.751 & 0.025 & $<0.001$ \\
\hline 9 & 0.796 & 0.018 & $<0.001$ & 0.814 & 0.037 & $<0.001$ & 0.793 & 0.021 & $<0.001$ \\
\hline 10 & 0.756 & 0.024 & $<0.001$ & 0.889 & 0.023 & $<0.001$ & 0.802 & 0.021 & $<0.001$ \\
\hline 11 & 0.781 & 0.023 & $<0.001$ & 0.850 & 0.038 & $<0.001$ & 0.791 & 0.025 & $<0.001$ \\
\hline 12 & 0.734 & 0.024 & $<0.001$ & 0.784 & 0.039 & $<0.001$ & 0.743 & 0.023 & $<0.001$ \\
\hline 13 & 0.722 & 0.021 & $<0.001$ & 0.802 & 0.026 & $<0.001$ & 0.763 & 0.020 & $<0.001$ \\
\hline 14 & 0.763 & 0.022 & $<0.001$ & 0.852 & 0.022 & $<0.001$ & 0.778 & 0.021 & $<0.001$ \\
\hline 15 & 0.741 & 0.018 & $<0.001$ & 0.797 & 0.035 & $<0.001$ & 0.755 & 0.020 & $<0.001$ \\
\hline 16 & 0.749 & 0.018 & $<0.001$ & 0.895 & 0.020 & $<0.001$ & 0.802 & 0.018 & $<0.001$ \\
\hline 17 & 0.773 & 0.021 & $<0.001$ & 0.782 & 0.047 & $<0.001$ & 0.761 & 0.022 & $<0.001$ \\
\hline 18 & 0.755 & 0.025 & $<0.001$ & 0.770 & 0.042 & $<0.001$ & 0.728 & 0.023 & $<0.001$ \\
\hline $7-10$ & 0.731 & 0.014 & $<0.001$ & 0.803 & 0.020 & $<0.001$ & 0.753 & 0.013 & $<0.001$ \\
\hline $10-14$ & 0.729 & 0.011 & $<0.001$ & 0.822 & 0.015 & $<0.001$ & 0.759 & 0.011 & $<0.001$ \\
\hline $1-18$ & 0.748 & 0.010 & $<0.001$ & 0.816 & 0.018 & $<0.001$ & 0.766 & 0.010 & $<0.001$ \\
\hline
\end{tabular}

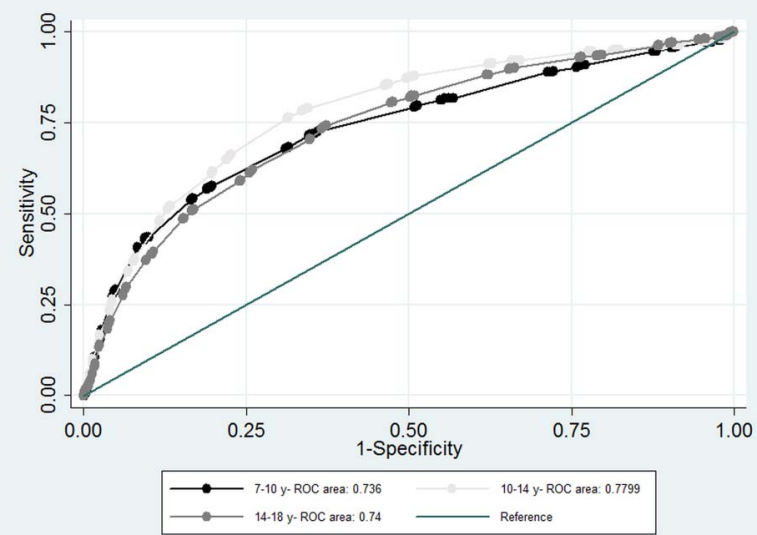

Figure 1 Receiver operating characteristic curve of neck circumference for predicting obesity in Iranian children and adolescents by age categories. ROC, receiver operating characteristic.

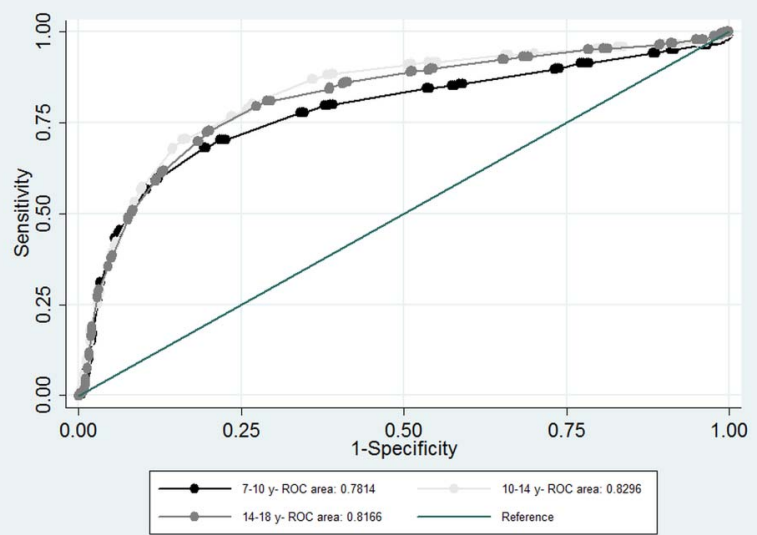

Figure 2 Receiver operating characteristic curve of neck circumference for predicting overweight in Iranian children and adolescents by age categories. ROC, receiver operating characteristic. 


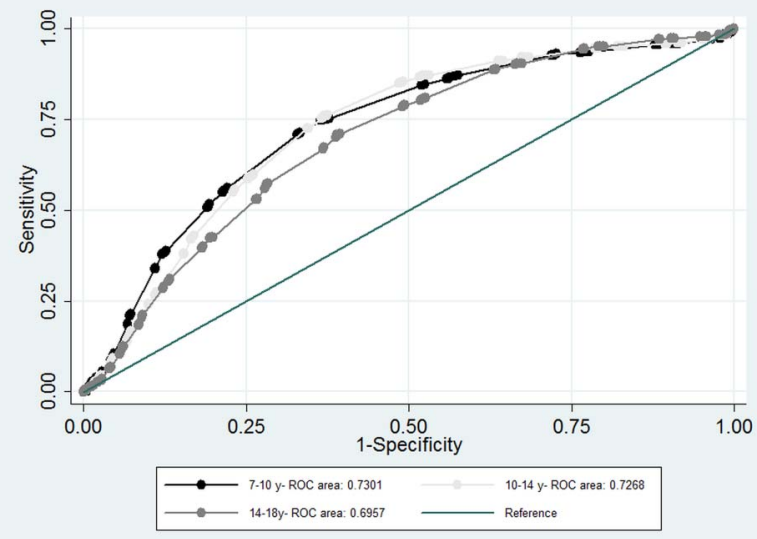

Figure 3 Receiver operating characteristic curve of neck circumference for predicting abdominal obesity in Iranian children and adolescents by age categories. ROC, receiver operating characteristic.
Furthermore, in this study, we were not able to measure fat mass as an indicator of excess weight, and obesity was defined according to BMI. Moreover, as in ROC analyses, the predictive values and likelihood ratios depend on the overall outcome prevalence (childhood obesity/ overweight), conclusions may not be applicable to other far different populations ${ }^{37}$ and these results are exclusively applicable at a national level, and possibly at a regional level.

\section{Conclusion}

Consistent with some previous studies in children and adolescents, the findings of the present investigation showed that NC could be proposed as an index of obesity/overweight in both genders of the paediatric age group. We propose that NC could be a useful screening measure for identifying overweight or obese children and adolescents at the population level.

Table 6 Threshold, sensitivity and specificity of neck circumference for detecting overweight, obesity and abdominal obesity in Iranian children and adolescents by sex and age groups: the CASPIAN IV study

\begin{tabular}{|c|c|c|c|c|c|c|c|c|c|}
\hline \multirow{2}{*}{$\begin{array}{l}\text { Age } \\
\text { (year)-sex } \\
\text { group }\end{array}$} & \multicolumn{3}{|c|}{ Overweight } & \multicolumn{3}{|c|}{ General obesity } & \multicolumn{3}{|c|}{ Abdominal obesity } \\
\hline & $\begin{array}{l}\text { Cut-off } \\
\text { point }\end{array}$ & Sensitivity & Specificity & $\begin{array}{l}\text { Cut-off } \\
\text { point }\end{array}$ & Sensitivity & Specificity & $\begin{array}{l}\text { cut-off } \\
\text { point }\end{array}$ & Sensitivity & Specificity \\
\hline \multicolumn{10}{|c|}{ Age group-boys } \\
\hline 7 & 27.05 & 0.63 & 0.73 & 27.05 & 0.76 & 0.72 & 26.45 & 0.71 & 0.68 \\
\hline 8 & 27.65 & 0.70 & 0.67 & 27.55 & 0.70 & 0.66 & 27.05 & 0.68 & 0.64 \\
\hline 9 & 28.05 & 0.64 & 0.74 & 28.55 & 0.76 & 0.77 & 27.95 & 0.75 & 0.63 \\
\hline 10 & 28.65 & 0.73 & 0.67 & 29.05 & 0.79 & 0.78 & 28.55 & 0.79 & 0.70 \\
\hline 11 & 29.55 & 0.76 & 0.71 & 30.75 & 0.87 & 0.85 & 29.95 & 0.79 & 0.76 \\
\hline 12 & 30.55 & 0.74 & 0.73 & 31.05 & 0.81 & 0.81 & 30.65 & 0.78 & 0.78 \\
\hline 13 & 31.45 & 0.73 & 0.71 & 32.05 & 0.77 & 0.78 & 31.05 & 0.72 & 0.75 \\
\hline 14 & 32.05 & 0.67 & 0.67 & 32.80 & 0.77 & 0.71 & 31.90 & 0.72 & 0.60 \\
\hline 15 & 33.45 & 0.70 & 0.65 & 34.95 & 0.83 & 0.78 & 33.80 & 0.75 & 0.69 \\
\hline 16 & 34.95 & 0.78 & 0.64 & 36.05 & 0.82 & 0.82 & 35.05 & 0.70 & 0.77 \\
\hline 17 & 35.45 & 0.70 & 0.61 & 36.60 & 0.78 & 0.76 & 35.90 & 0.74 & 0.66 \\
\hline 18 & 36.05 & 0.67 & 0.68 & 37.10 & 0.73 & 0.77 & 36.15 & 0.73 & 0.71 \\
\hline $7-10$ & 27.85 & 0.74 & 0.63 & 28.05 & 0.70 & 0.75 & 27.35 & 0.71 & 0.61 \\
\hline $10-14$ & 30.15 & 0.76 & 0.63 & 31.95 & 0.78 & 0.76 & 30.75 & 0.77 & 0.71 \\
\hline $14-18$ & 34.95 & 0.72 & 0.60 & 36.06 & 0.78 & 0.80 & 35.05 & 0.71 & 0.73 \\
\hline \multicolumn{10}{|c|}{ Age group_-girls } \\
\hline 7 & 25.90 & 0.70 & 0.61 & 27.05 & 0.81 & 0.81 & 25.90 & 0.67 & 0.62 \\
\hline 8 & 26.25 & 0.69 & 0.63 & 27.15 & 0.67 & 0.76 & 26.55 & 0.70 & 0.69 \\
\hline 9 & 27.95 & 0.82 & 0.70 & 28.05 & 0.77 & 0.77 & 27.95 & 0.79 & 0.71 \\
\hline 10 & 28.55 & 0.76 & 0.73 & 29.90 & 0.89 & 0.84 & 28.45 & 0.75 & 0.72 \\
\hline 11 & 29.05 & 0.76 & 0.72 & 30.25 & 0.82 & 0.82 & 29.05 & 0.76 & 0.72 \\
\hline 12 & 30.05 & 0.69 & 0.71 & 30.90 & 0.78 & 0.73 & 30.05 & 0.67 & 0.72 \\
\hline 13 & 31.10 & 0.65 & 0.68 & 32.05 & 0.71 & 0.79 & 31.25 & 0.72 & 0.71 \\
\hline 14 & 31.90 & 0.78 & 0.67 & 32.25 & 0.78 & 0.76 & 31.65 & 0.72 & 0.68 \\
\hline 15 & 32.05 & 0.62 & 0.71 & 32.90 & 0.78 & 0.72 & 32.05 & 0.68 & 0.73 \\
\hline 16 & 32.60 & 0.70 & 0.69 & 34.10 & 0.81 & 0.86 & 32.75 & 0.76 & 0.72 \\
\hline 17 & 32.85 & 0.80 & 0.68 & 33.05 & 0.73 & 0.74 & 32.95 & 0.72 & 0.71 \\
\hline 18 & 32.96 & 0.75 & 0.66 & 33.25 & 0.73 & 0.73 & 32.20 & 0.72 & 0.64 \\
\hline $7-10$ & 27.45 & 0.71 & 0.69 & 27.95 & 0.78 & 0.70 & 27.05 & 0.73 & 0.70 \\
\hline $10-14$ & 30.45 & 0.75 & 0.64 & 31.35 & 0.76 & 0.75 & 30.90 & 0.73 & 0.68 \\
\hline 14-18 & 32.85 & 0.70 & 0.70 & 33.45 & 0.77 & 0.77 & 32.55 & 0.71 & 0.72 \\
\hline
\end{tabular}


Author affiliations

'Department of Pediatrics, Child Growth and Development Research Center, Research Institute for Primordial Prevention of Non-communicable Disease, Isfahan University of Medical Sciences, Isfahan, Iran

${ }^{2}$ Non-communicable Diseases Research Center, Endocrinology and Metabolism Population Sciences Institute, Tehran University of Medical Sciences, Tehran, Iran

${ }^{3}$ Development of Research \& Technology Center, Deputy of Research and Technology, Ministry of Health and Medical Education, Tehran, Iran ${ }^{4}$ Department of Pediatrics, Ahvaz Jundishapur University of Medical Sciences, Ahvaz, Iran

${ }^{5}$ School of Humanities and Tourism Management, Bangkok University, Bangkok, Thailand

${ }^{6}$ Department of Exercise Physiology, Science and Research Branch, Islamic Azad University, Tehran, Iran

${ }^{7}$ Managerial Epidemiology Research Center, Department of Public Health, School of Nursing and Midwifery, Maragheh University of Medical Sciences, Maragheh, Iran ${ }^{8}$ Department of Nutrition, School of School of Nutritional Sciences and Dietetics, Tehran University of Medical Sciences, Tehran, Iran ${ }^{9}$ Department of Medical Emergencies, Qom University of Medical Sciences, Qom, Iran

${ }^{10}$ Department of Health Education and Promotion, School of Health, Iran University of Medical Sciences, Tehran, Iran

${ }^{11}$ Department of Community Medicine, School of Medicine, Alborz University of Medical Sciences, Karaj, Iran

${ }^{12}$ Chronic Diseases Research Center, Endocrinology and Metabolism Population

Sciences Institute, Tehran University of Medical Sciences, Tehran, Iran

Acknowledgements The authors are thankful to the large team working on this study and all participants in different provinces.

Contributors RK and GA designed the study. MM and GA were involved in data collection. MQ, SS, SD and MB participated in statistical analysis and drafted the manuscript. TA, MH, HA and MM contributed to the drafting of the manuscript. Critical revision was carried out by RK, MQ and SS

Funding This research received no specific grant from any funding agency in the public, commercial or not-for-profit sectors.

Competing interests None declared

Ethics approval Tehran University of Medical Sciences.

Provenance and peer review Not commissioned; externally peer reviewed.

Data sharing statement No additional data are available.

Open Access This is an Open Access article distributed in accordance with the Creative Commons Attribution Non Commercial (CC BY-NC 4.0) license which permits others to distribute, remix, adapt, build upon this work noncommercially, and license their derivative works on different terms, provided the original work is properly cited and the use is non-commercial. See: http:// creativecommons.org/licenses/by-nc/4.0/

\section{REFERENCES}

1. Finucane MM, Stevens GA, Cowan MJ, et al. National, regional, and global trends in body-mass index since 1980: systematic analysis of health examination surveys and epidemiological studies with 960 country-years and 9Â 1 million participants. Lancet 2011;377:557.

2. Kelishadi R. Childhood overweight, obesity, and the metabolic syndrome in developing countries. Epidemiol Rev 2007;29:62.

3. Dietz WH, Robinson TN. Overweight children and adolescents. N Engl J Med 2005;352:2100-9.

4. Djalalinia S, Qorbani M, Peykari N, et al. Health impacts of Obesity. Pak J Med Sci 2015;31:239.

5. Must A, Spadano J, Coakley EH, et al. The disease burden associated with overweight and obesity. JAMA 1999;282:1523.

6. Ben-Noun L, Sohar E, Laor A. Neck circumference as a simple screening measure for identifying overweight and obese patients. Obes Res 2001;9:470-7.

7. Rothman KJ. BMI-related errors in the measurement of obesity. Int J Obes (Lond) 2008;32(Suppl 3):S56.

8. Organization $\mathrm{WH}$, Organization $\mathrm{WH}$. Obesity: preventing and managing the global epidemic: report of a WHO consultation. WHO Tech Rep Ser 1999;894:i-xii, 1-253.
9. Walton C, Lees B, Crook D, et al. Body fat distribution, rather than overall adiposity, influences serum lipids and lipoproteins in healthy men independently of age. Am J Med 1995;99:459.

10. Miller JZ, Slemenda CW, Meaney FJ, et al. The relationship of bone mineral density and anthropometric variables in healthy male and female children. Bone Miner 1991;14:137.

11. Wills SD, Bhopal RS. The challenges of accurate waist and hip measurement over clothing: pilot data. Obes Res Clin Pract 2010;4: e239-44.

12. Nafiu OO, Burke $\mathrm{C}$, Lee J, et al. Neck circumference as a screening measure for identifying children with high body mass index. Pediatrics 2010;126:e306.

13. Ben-Noun L, Laor A. Relationship of neck circumference to cardiovascular risk factors. Obes Res 2003;11:226.

14. Hatipoglu N, Mazicioglu MM, Kurtoglu S, et al. Neck circumference: an additional tool of screening overweight and obesity in childhood Eur J Pediatr 2010;169:733.

15. Tatar BT, Ersoy C, Kacan T, et al. Neck and Wrist Circumferences Propose a Reliable Approach to Qualify Obesity and Insulin Resistance.

16. Olshansky SJ, Passaro DJ, Hershow RC, et al. A potential decline in life expectancy in the United States in the 21st century. $N$ Engl $J$ Med 2005;352:1138.

17. Kelishadi R, Ardalan G, Qorbani M, et al. Methodology and early findings of the fourth survey of childhood and adolescence surveillance and prevention of adult non-communicable disease in Iran: the CASPIAN-IV study. Int J Prev Med 2013;4:1451.

18. WHO Multicentre Growth Reference Study Group. WHO Child Growth Standards based on length/height, weight and age. Acta Paediatr Suppl 2006;450:76-85.

19. Ogden CL, Flegal KM. Changes in terminology for childhood overweight and obesity. Natl Health Stat Report 2010:1-5.

20. Cruz ML, Goran MI. The metabolic syndrome in children and adolescents. Curr Diab Rep 2004;4:53.

21. Perkins NJ, Schisterman EF. The inconsistency of "optimal" cutpoints obtained using two criteria based on the receiver operating characteristic curve. Am J Epidemiol 2006;163:670-5.

22. World Health Organization. Obesity: preventing and managing the global epidemic. World Health Organization, 2000.

23. Stradling JR, Crosby JH. Predictors and prevalence of obstructive sleep apnoea and snoring in 1001 middle aged men. Thorax 1991;46:85.

24. Katz SL, Vaccani J-P, Clarke J, et al. Creation of a reference data set of neck sizes in children: standardizing a potential new tool for prediction of obesity-associated diseases? BMC Pediatr 2014;14:159.

25. Nagy $P$, Kovacs E, Moreno LA, et al. Centile reference values for anthropometric body composition indices in European children from the IDEFICS study. Int J Obes 2014;38:S15-25.

26. Preis SR, Massaro JM, Hoffmann U, et al. Neck circumference as a novel measure of cardiometabolic risk: the Framingham Heart study. J Clin Endocrinol Metab 2010;95:3701-10.

27. de Lucena Ferretti R, de Pádua Cintra I, Passos MAZ, et al. Elevated neck circumference and associated factors in adolescents. BMC Public Health. 2015;15:208.

28. Katz S, Vaccani J, Barrowman $\mathrm{N}$, et al. Does neck-to-waist ratio predict obstructive sleep apnea in children? J Clin Sleep Med 2014;10:1303.

29. Coutinho CA, Longui CA, Monte $O$, et al. Measurement of neck circumference and its correlation with body composition in a sample of students in São Paulo, Brazil. Horm Res Paediatr 2014;82:179-86.

30. Lou D-H, Yin F-Z, Wang R, et al. Neck circumference is an accurate and simple index for evaluating overweight and obesity in Han children. Ann Hum Biol 2012;39:161-5.

31. Lobstein T, Baur L, Uauy R; IASO International Obesity Task Force. Obesity in children and young people: a crisis in public health. Obes Rev 2004:5:4-104.

32. Kurtoglu S, Hatipoglu N, Mazicioglu MM, et al. Neck circumference as a novel parameter to determine metabolic risk factors in obese children. Eur J Clin Invest 2012:42:623-30.

33. Nafiu O, Zepeda A, Curcio C, et al. Association of neck circumference and obesity status with elevated blood pressure in children. J Hum Hypertens 2014;28:263-8.

34. Androutsos O, Grammatikaki E, Moschonis G, et al. Neck circumference: a useful screening tool of cardiovascular risk in children. Pediatr Obes 2012;7:187-95.

35. LaBerge RC, Vaccani JP, Gow RM, et al. Inter- and intra-rater reliability of neck circumference measurements in children. Pediatr Pulmonol 2009;44:64

36. Davies RJ, Stradling JR. The relationship between neck circumference, radiographic pharyngeal anatomy, and the obstructive sleep apnoea syndrome. Eur Respir J 1990;3:509.

37. Van der Schouw YT, Verbeek AL, Ruijs JH. ROC curves for the initial assessment of new diagnostic tests. Fam Pract 1992;9:506. 